\title{
THE ROLE OF INPUT IN SECOND LANGUAGE ACQUISITION
}

\author{
Taher Bahrani \\ Department of English, Mahshahr Branch, Islamic Azad University, Mahshahr, Iran. \\ taherbahrani@yahoo.com \\ Marziyeh Nekoueizadeh \\ Department of English Language, Sepidan Branch, Islamic Azad University, Sepidan, Iran \\ 693mnekooei@gmail.com
}

\begin{abstract}
There are many internal as well as external factors which influence second language acquisition (SLA). Among them, the language input that learners receive in SLA is one of the external factors which plays a fundamental role. In this regard, Corder (1967) is one of the pioneers among SLA researchers who underscored the importance of language input for SLA by drawing a distinction between input and intake. According to Corder, language input refers to what is available to be utilized by language learners for SLA which should be differentiated from intake which is that part of the input which is comprehended by the language learners. In the same line, the present paper is an attempt to highlight the role of language input from the viewpoints of different SLA theories. The paper also focuses on Krashen's input hypothesis as one of the influential hypothesis with regard to the role of language input in SLA development.
\end{abstract}

\section{Indexing terms/Keywords}

Second language acquisition; Language input; Intake; Comprehension.

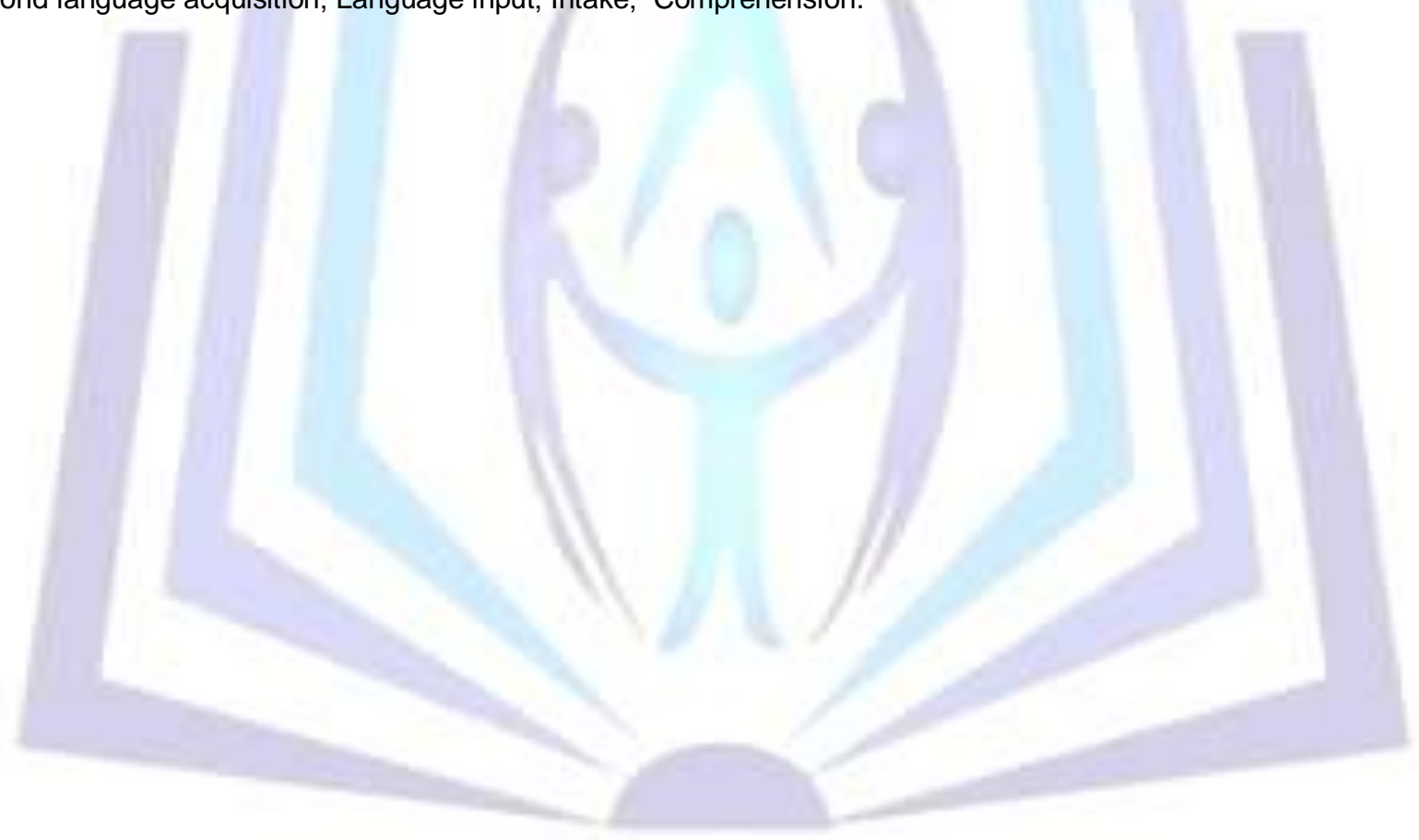

\section{Council for Innovative Research}

Peer Review Research Publishing System

Journal: Journal of Advances in Linguistics

Vol 1, No.1

editor@cirworld.com

www.cirworld.com, member.cirworld.com 


\section{THE ROLE OF INPUT IN SECOND LANGUAGE ACQUISITION}

The review of the literature on language input and SLA reveals that much work in this area of research has been concerned with the importance, the role, and the processing of linguistic input (Doughty \& Long, 2003; Ellis, 1994; Ellis, 1997; Gass \& Selinker, 1994; Gass, 1997; Grady, Lee \& Lee, 2011; Hart \& Risley, 1995; Long, 1982; Nasaji \& Fotos, 2010; Patten \& Benati, 2010; Pica, Young \& Doughty, 1987; VanPatten \& Williams, 2007; Williams, Ritchie \& Taj, 1999). From this large pool of research, it can be deduced that SLA simply cannot take place in a vacuum without considering having exposure to some sort of language input (Gass, 1997).

However, while the importance and the role of language input have been advocated by various theories of language learning, there has been a difference between those theories which attribute a small or no role to language input and those attributing it a more important role. According to Ellis $(1994 ; 2008)$, SLA theories attach different importance to the role of input in the language acquisition process but they all acknowledge the need for language input. In many SLA theories, language input is considered as being a highly essential factor while in other theories it has been given the secondary role. In fact, what has been changed in relation to the role of input in language learning from the viewpoint of various language learning theories is the conceptualization of how language input is processed by language learners (Doughty \& Long, 2003).

In this relation, Ellis (2008) considered the role of language input in SLA based on behaviorist, mentalist, and interactionist theories of language learning. The behaviorists view language learning as environmentally controlled by various stimulus and feedback that language learners are exposed to as language input. Indeed, the behaviorists consider a direct relationship between input and output. They ignore the internal processes of the mind for language acquisition. For the behaviorists, language acquisition is controlled by external factors among which language input which consists of stimuli and feedback is central (Ellis, 2008).

The mentalist theories also claim that input is needed for SLA but because the learners' brains are equipped to learn any language with innate knowledge, language input is merely considered as a trigger that activates the internal mechanism (Ellis, 2008). The interactionists theories of SLA highlight the importance of both input and internal language learning processing. They view language acquisition as the outcome of an interaction at the discourse level between the learners' mental abilities and the linguistic environment and input as the role of affecting or being affected by the nature of internal mechanisms (Ellis, 2008).

Other theories that underscore the important role of language input in SLA are the information processing and skillacquisition theories (Nassaji \& Fotos, 2010). According to Nassaji and Fotos (2010), the role of language input in information processing theories is important because it is the information embedded in the input and its frequency that help language learners acquire the target language. Moreover, language input is essential in skill-acquisition theories because it forms learners' initial declarative knowledge which refers to the knowledge about the language. Other researches in spoken languages also indicate that the amount of language in the input and its frequency are indeed highly relevant for the acquisition of language (Hart \& Risley, 1995; Ellis, 1997).

Gass (1997) also considered the role of language input in the input-interaction model, the input hypothesis, the universal grammar model, and the information processing model which treat the role of language input in different ways. According to Gass (1997), in the input-interaction model, the language input that language learners receive is strengthened by the manipulation of the input through interaction which forms a basis for SLA. Within Krashen's comprehensible input hypothesis (1981), SLA takes place merely by means of comprehensible input which the language learners receive. That is, only the language input that is a little beyond the learners' language competence is useful for SLA. The third model as explained by Gass (1997) is the universal grammar which asserts that language input is important but there must be something in addition to language input. This is the innate capacity which helps language learners acquire the second language. The last model is the information processing model in which the learner must first notice that there is something to learn. Then, the learner's attention is drawn to those parts of the input which do not coincide with the internalized competence. In this model, language input is necessary for providing information for language construction (Gass, 1997).

The role of input in SLA has been highlighted as constituting the primary data for SLA (Long, 1982; Pica et al., 1987; VanPatten \& Williams, 2007). Patten and Benati (2010) have emphasized that language input is a major source of data for language learners to construct their competence or mental representation of the language based on the examples embedded in the input. Grady et al. (2011) also highlighted the role of input in SLA by noting that in some cases of SLA there are indications that at least some features such as lexical development are directly shaped by the input. In other words, the language acquisition process is dependent upon the availability of appropriate language input.

Besides the role of language input in SLA which has been considered from the perspectives of different language learning theories and models, language input has also been given the initial role to provide the necessary data for SLA in some frameworks. Among the researchers who have studied the role of language input in SLA, Gass and Selinker (1994) and Ellis (1997) proffered two frameworks which indicate the importance of input in the SLA process.

Within the framework introduced by Gass and Selinker (1994), there are five levels for turning input into output: apperceived input, comprehended input, intake, integration, and output which account for the SLA process. According to their model (Figure 1), language input refers to various sources of second language data which the learners are exposed to. 


\section{Apperceived input}

$\sqrt{6}$

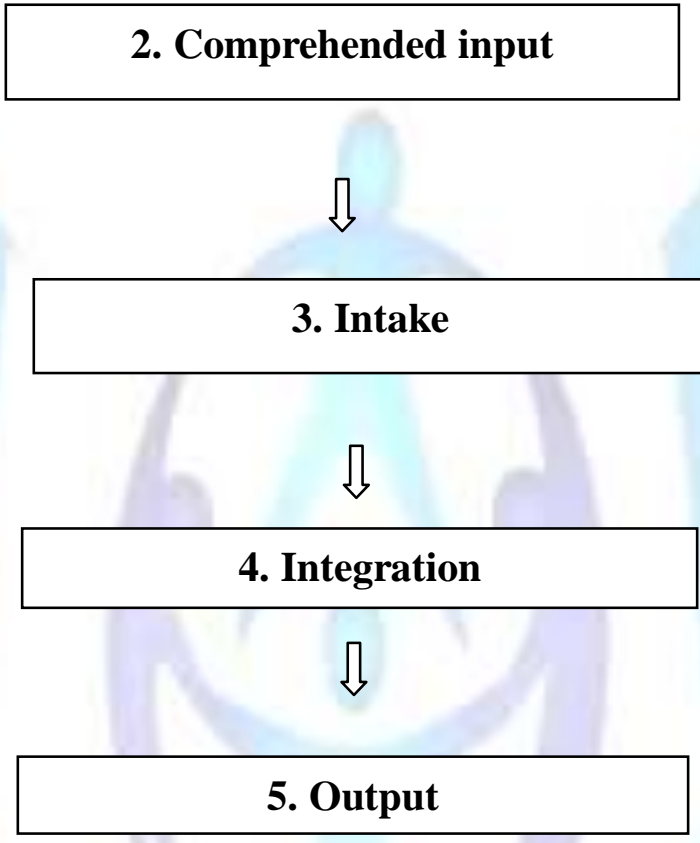

Figure 1: Gass and Selinker's model (1994) for second language acquisition

The first stage of the SLA model which is concerned with input utilization is called apperceived input. In this stage, some of the language input is noticed by the language learner because of some specific features such as frequency, prior knowledge, affect, and attention (Gass \& Selinker, 1994). The second stage is the comprehension of that bit of language input which is apperceived. Then, in the third stage which is a mental activity, the language input is comprehended and internalized by the language learners which refers to intake. The fourth stage is the integration of the intake with the prior knowledge to arrive at the fifth stage which is the output in the form of written or spoken language.

Likewise, Ellis (1997) introduced a basic computational model of SLA with an initial focus on language input (Figure 2). In this model, language learners are first exposed to language input which is then processed in two stages. First, some parts of the input that are comprehended by the language learners turn into intake. Second, some of the intake which finds its way to the long term memory is then turned into knowledge which results in spoken or written output. While Gass and Selinker's (1994) and Ellis's (1997) theoretical frameworks for SLA attach the initial importance to language input, they differ from each other in the number of stages that language input is processed in the minds of language learners.

\section{INPUT $\Longrightarrow$ INTAKE $\Longrightarrow$ KNOWLEDGE $\rightleftharpoons$ OUTPUT}

Figure 2: Ellis's model (1997) for second language acquisition

In a nutshell, both the above-mentioned frameworks are concerned with the various steps in which language input is turned into output. In other words, the language input processing is the focus of both frameworks. However, comparing the theories and theoretical frameworks for SLA based on the role of language input, it is revealed that the importance of language input is highlighted by various theories and theoretical frameworks for SLA. Taking up on this, one of the most influential SLA hypotheses concerned with the role and importance of language input in SLA is the input hypothesis (Krashen, 1981, 1982, 1985). Indeed, most of the studies on the type of language input and SLA have been developed to either support or criticize Krashen's input hypothesis which first claimed the important role of comprehensible input for 
SLA. Indeed, input hypothesis triggered numerous studies in the investigation of issues related to the type of language input for SLA (Ying, 1994).

\section{KRASHEN'S INPUT HYPOTHESIS AND SECOND LANGUAGE ACQUISITION}

One of the important psychologically-oriented theories of language learning was established by Krashen (1981, 1982, 1985). He proposed a 'monitor model' of second language learning including five hypotheses: the input hypothesis, the natural order hypothesis, the acquisition-learning hypothesis, the monitor hypothesis, and the affective filter hypothesis. The hypothesis related to this study is the input hypothesis which is put forth.

As was discussed in the previous section (2.1.1), language input is considered as a highly important factor in the SLA process. In this relation, the input hypothesis continues to make strong claims regarding the role of language input and the necessity of exposure to comprehensible language input in SLA. The input hypothesis strongly claims that for SLA to take place, language learners should have exposure to a type of second language data which they can comprehend. Krashen identified comprehensible language input as "the only causative variable in SLA" (Krashen, 1981, p. 57). According to Krashen, for SLA to occur, language learners have to have exposure to comprehensible language input that includes language structures that are beyond their current level $(i+1)$.

Based on Krashen's claims regarding language input and SLA, the basic assumptions of the input hypothesis are summarized as: (1) access to comprehensible input is the main feature of all cases of effective SLA, (2) more quantities of comprehensible input seem to cause faster or better SLA, and (3) lack of access to comprehensible input causes little or no SLA.

A few researchers (Ellis \& He, 1999; Gass \& Varonis, 1994; Long, 1982) have advocated the input hypothesis by suggesting modified input, interactionally modified input, and modified output as three rich sources of comprehensible input for SLA. Modified input refers to a type of language input that has been modified or simplified in some ways before the language learners are exposed to it, interactionally modified input, on the other hand, originates from input modification that occurs when language learners experience difficulty comprehending a message in interaction with interlocutors, and modified output refers to language learners' efforts to modify their output to make it more comprehensible to the interlocutor (Ellis \& He, 1999; Long, 1996).

Another aspect of the input hypothesis in relation to acquiring the language in informal settings (out of the classroom environment) is the importance of direct exposure to a source of language input. According to Krashen (1981), language acquisition can take place in an informal environment if language learners are directly involved in intensive exposure to language input. Later, it will be discussed that this aspect of the input hypothesis which emphasizes the necessity of exposure to language input for language learning to occur has also been emphasized by Krashen's critics. Nevertheless, empirical evidence related to the sources of language input, the quality, and quantity of the input have not been provided neither by Krashen nor his critics.

\section{CRITIQUES OF THE INPUT HYPOTHESIS}

Regardless of the significant effect that the input hypothesis has had on the researches about the role of language input in SLA, it has been criticized strongly by several researchers. Serious concerns regarding the input hypothesis were expressed by McLaughlin (1987). McLaughlin claimed that it is very difficult to define the concept of a learner's level which limits the application of its rule in the classroom because individual differences should be taken into consideration when determining the learners' current levels. In fact, determining the current level of each language learner and providing i+1 language input for each of them separately in the classroom seems to be very difficult to fulfill. Krashen did not provide solutions considering this issue. There are also some problems regarding the approach to provide language learners with language input which matches their $\mathrm{i}+1$ level.

The input hypothesis has also been challenged by many researchers particularly because it has made a large number of claims about the type and the qualitative aspect of the necessary language input for SLA development without providing solid empirical evidence. In other words, because Krashen's input hypothesis limits SLA to merely exposure to comprehensible input, the criticisms directed at the input hypothesis are mainly around the nature and the type of language input that can constitute the primary data for SLA. In fact, although second language researchers and the critics of Krashen's input hypothesis highlight the important role of input in SLA and agree on the fact that language input is a necessary ingredient in SLA (Salaberry, 2003), they claim that SLA is not achieved merely through comprehensible input. Other types of language input such as incomprehensible input, comprehended input, and comprehensible output are also considered to improve language learning through providing the necessary input.

White (1987) considered the necessary language input which constitutes the primary data for SLA to be either comprehensible or incomprehensible. In his incomprehensible input hypothesis, White underscored the point that it is the comprehension difficulties or input incomprehensibility that can provide important negative feedback to the learner that is indispensable for the constitution of SLA. When language learners encounter language input that is incomprehensible to them because their inter-language rules cannot, for example, analyze a particular structure, they have to modify those inter-language rules to understand the structure (White, 1987). As a result, the incomprehensible input enhances SLA.

It can be concluded from what White (1987) has put forth in relation to comprehensible or incomprehensible input that when the language input is comprehensible, the acquisition of the missing structures may not occur. In contrast, when the language input is incomprehensibility because of some aspects which the language learners have not yet acquired, the given language input to the language learners draws their attention to the specific features to be acquired. 
Gass $(1988,1997)$ also emphasized that priority should be attached to the concept of comprehended input rather than comprehensible input. According to Gass, only that part of the language input which is comprehended is involved in the SLA process. In other words, the primary language input which is necessary for SLA may be beyond the boundaries of comprehensible input.

In the same line and as was discussed earlier, in Gass and Selinker's (1997) and Ellis's (1994) theoretical models for SLA, language input which is apperceived by the language learners and then is turned into comprehended input and intake is not limited merely to language data (input) which should necessarily be comprehensible. Indeed, language learners are exposed to a body of second language input which may or may not be within the range of $i+1$. Out of this initial body of language input, some of the input is noticed by the language learners because of frequency, affect, prior knowledge, and attention (Gass \& Selinker, 1997). Hence, the qualitative aspect of language input in Gass and Selinker's (1997) and Ellis's (1994) theoretical models for SLA is not limited to language input that is necessarily at the language learners' $i+1$ current language proficiency level.

In addition to incomprehensible input and comprehended input, Swain (1985) also argued that besides comprehensible input, comprehensible output can also provide the necessary data for SLA. The comprehensible output hypothesis put forth by Swain (1985) states that language learning occurs when the language learner faces a gap in his/her linguistic knowledge of the second language. By noticing this gap, the language learner tries to modify his/her output. This modification of output may end in learning a new aspect of the language which has not been acquired yet.

Although Swain did not claim that comprehensible output is solely responsible for all or even most parts of the language acquisition, she highlighted the point that under some conditions, comprehensible output facilitates SLA in ways that it can provide the necessary input. As a matter of fact, although Swain (1985) acknowledged that without comprehensible input language learners are not able to make connections between forms and meanings for SLA development, she provided evidence of the immersion programs in which comprehensible input alone did not lead to SLA. This view sharply contrasts with Krashen's input hypothesis where the role of comprehensible output is neglected or minimized.

The input hypothesis underscores the point that increased comprehensible input causes more language acquisition not the increased output. Yet, no evidence has been provided for this claim. In this regard, Romeo (2000) showed support for Swain's comprehensible output hypothesis when he indicated that output of some kind is considered as a necessary phase in SLA.

Romeo (2000) highlighted the role of output in SLA by underlying the point that teachers need language learners' output to be able to judge their improvement and adapt future materials to their needs. Moreover, language learners need the opportunity to use the second language because when faced with communication failure, they are forced to make their output more precise. These arguments suggest that both comprehensible input and comprehensible output are important to be utilized as a source of input in SLA process. This view goes against Krashen's input hypothesis.

To this point, according to what was put forth in relation to Krashen's input hypothesis and his critiques' concerns, it can be concluded that the importance of language input for SLA is not questioned and some type of language input is necessary for SLA. Accordingly, in addition to modified input, interactionally modified input, and modified output which are considered as various types of comprehensible input for SLA, comprehended input, incomprehensible input, and comprehensible output can also provide the necessary language input for SLA. Hence, without debating on the right or wrong of Krashen's hypothesis which is beyond the scope of this study, the premise taken is that some forms of language input is necessary for the study without delving into the psychological aspects of the language input.

The controversial issues in relation to language input are the type and the amount (quantity) of language input necessary for SLA which have also been highlighted by Gass (1997). As a matter of fact, although the importance of input in SLA has been emphasized by the majority of the researchers, little has also been written about the type and amount of language input for SLA. In fact, the studies on the role and importance of language input in SLA fall short of providing evidence of the sources of language input which can provide the necessary language input for SLA in informal settings particularly in EFL contexts. In the same line, the focus of the present research is on the sources of language input and the impact on language proficiency.

\section{CONCLUSION}

Second language acquisition simply cannot take place in vacuum. In fact, for second language acquisition (SLA), having access to language input is critical. While the importance and the role of language input have been advocated by various theories of language learning, there has been a controversy over the extent of its importance. In fact, what has been changed in relation to the role of input in language learning from the viewpoint of various language learning theories is the conceptualization of how language input is processed by language learners (Doughty \& Long, 2003).

\section{REFERENCES}

[1] Corder, S. P. (1967). The significance of learners' errors. International Review of Applied Linguistics, 5, $161-170$.

[2] Doughty, C., \& Long, M. H. (2003). The handbook of second language acquisition. Blackwell publishing.

[3] Ellis, R. (1994). The study of Second language acquisition. Oxford: Oxford University Press.

[4] Ellis, R. (1997). Second language acquisition. Oxford: Oxford University Press. 
[5] Ellis, R. (1999). Learning a second language through interaction (pp. 238 - 239). Amsterdam/ Philadelphia: John Benjamins.

[6] Ellis, R. (2008). The study of Second language acquisition (second ed). Oxford: Oxford University Press.

[7] Ellis, R., \& He, X. (1999). The roles of modified input and output in the incidental acquisition of word meanings. Studies in Second Language Acquisition, 21, 285-301.

[8] Gass, S. M. (1988). Integrating research areas: A framework for second language studies. Applied Linguistics, 9 , 198-217.

[9] Gass, S. M. (1997). Input, interaction, and the second language learner. Mahwah, NJ: Lawrence Elrbaum.

[10] Gass, S., \& Selinker, L. (1994). Second language acquisition: an introductory course. Hilldale, NJ: Lawrence Erlbaum Associates.

[11] Gass, S., \& Varonis, E. (1994). Input, Interaction, and Second language production. Studies in Second Language Acquisition, 16, 283-302.

[12] Grady, W., Lee, S, O. \& Lee, J. H. (2011). Practical and Theoretical Issues in the Study of Heritage Language Acquisition. Heritage Language Journal. (NO PAGE NUMBER)

[13] Hart, B., \& Risley, T. (1995). Meaningful differences in the everyday experience of young American children. Baltimore: Paul H. Brookes Publishing. (2004 printing).

[14] Krashen, S. (1981). Second language acquisition and second language learning. Oxford: Pergamon Press.

[15] Krashen, S. (1982). Principles and practice in second language acquisition. New York: Prentice Hall.

[16] Krashen, S. (1985). The input hypothesis. Torrance, CA: Laredo Publishing Company.

[17] Long, M. (1982). Native speaker/non-native speaker conversation in the second language classroom. In M. Long \& C. Richards (Eds.), Methodology in TESOL: A book of readings (pp. 339-354). New York: Newbury House.

[18] Long, M. (1996). The role of the linguistic environment in second language acquisition. In W. C. Ritchie \& T. K. Bhatia (Eds.), Handbook of second language acquisition (pp. 413-468). New York: Academic Press.

[19] McLaughlin, B. (1978). The monitor model: some methodological considerations. Language learning, 28, 309-332.

[20] Nassaji, H., \& Fotos, S. (2011). Teaching Grammar in Second Language Classrooms: Integrating form-focused instruction in communicative context. New York: Routlege Publishing.

[21] Patten, V. B., \& Benati, A. G. (2010). Key terms in second language acquisition. Continuum international publishing group. London.

[22] Pica, T., Young, R., \& Doughty, C. (1987). The impact of interaction on comprehension. TESOL Quarterly, 21, 737759.

[23] Romeo, K. (2000). Krashen and Terrell's "Natural Approach". Retrieved December 12, 2006, from http://www.stanford.edu/ kenro/LAU/ICLangLit/NaturalApproach.html.

[24] Salaberry, M. R. (2001). The use of technology for second language learning and teaching: A retrospective. Modern Language Journal, 85(1), 39-56.

[25] Swain, M. (1985). Communicative competence: Some roles of comprehensible input and comprehensible output in its development, Input in Second Language Acquisition., eds S. Gass \& C. Madden, Newbury House, Rowley, Mass.

[26] Ying, H. (1994). What sort of input is needed for intake? SLAT student association working papers, 2(1), 28-40.

[27] VanPatten, W, \& Williams, J. (2007). Theories in second language acquisition: An introduction. Lawrence Erlbaum Associates: New York.

[28] White, L (1987). Against comprehensible input: The Input Hypothesis and the development of L2 competence. Applied linguistics, 8, 95-110.

[29] Williams, C., Ritchie., \& Taj, K, B. (1999). Handbook of child language acquisition. San Diego, CA: Academic Press. 